\title{
Identification and Functional Analysis of Two Novel PAX9 Mutations
}

\author{
Ying Wang ${ }^{a}$ Hua $W^{b}{ }^{b}$ Jingfeng $W^{a}{ }^{a}$ Hongshan Zhao ${ }^{c}$ Xiaoxia Zhang ${ }^{b}$ \\ Gabriele Mues $^{\text {a }}$ Rena N. D'Souza ${ }^{a}$ Hailan Feng ${ }^{b}$ Hitesh Kapadia ${ }^{a}$ \\ ${ }^{a}$ Department of Biomedical Sciences, Baylor College of Dentistry, Texas A\&M University System Health Science \\ Center, Dallas, Tex., USA; ${ }^{b}$ Department of Prosthodontics, Peking University School and Hospital of Stomatology \\ and ${ }^{\mathrm{C}}$ Department of Immunology, School of Basic Medicine and Human Disease Genomics Center, Peking University, \\ Beijing, PR China
}

\section{Key Words}

Oligodontia $\cdot$ Tooth agenesis $\cdot$ PAX9 $\cdot$ Bmp4 $\cdot$ Missense mutation

\begin{abstract}
The paired-domain transcription factor PAX9 plays a critical role in tooth development, as heterozygous mutations in $P A X 9$ have been shown to be associated with human tooth agenesis. In this study, we report 2 novel missense mutations, gly6arg (G6R) and ser43lys (S43K), in the paired domain of PAX9 in Chinese patients with varying degrees of nonsyndromic tooth agenesis. Excluding third molars, the individual with the G6R mutation was missing 2 mandibular incisors and a maxillary premolar, while the phenotype of individuals with the S43K mutation consisted of peg-shaped upper lateral incisors and missing molars, premolars and canines. As these 2 mutations occur at highly conserved amino acids in the PAX gene family and between different species, we further analyzed the effects of the mutations on the function of the resulting proteins. Immunofluorescence and immunoblotting studies showed that the mutations did not alter nuclear localization in mammalian cells. Gel shift and
\end{abstract}

Y.W. and H.W. contributed equally to this paper.

\section{KARGER}

Fax +41613061234

E-Mail karger@karger.ch

www.karger.com (c) 2008 S. Karger AG, Basel

Accessible online at:

www.karger.com/cto super shift assays indicate that both mutant proteins bound DNA at a lower level than the normal protein, with G6R having a greater affinity for DNA than S43K. Likewise, the G6R protein was able to transcriptionally activate a Bmp4 promoter construct to a greater extent than S43K. Our finding that the severity of tooth agenesis in the patients was correlated to the DNA-binding capacity of the mutated PAX9 9 proteins supports the hypothesis that DNA binding is responsible for the genetic defect.

Copyright $\odot 2008$ S. Karger AG, Basel

\section{Introduction}

Tooth development involves a complex series of epithelial and mesenchymal signaling interactions [Thesleff, 2003]. Molecular and genetic studies in mice have revealed that more than 300 genes are involved in the process [Thesleff, 2006]. Among these, transcription factors

\section{Abbreviations used in this paper}

DHPLC denaturing high-performance liquid chromatography EMSA electrophoretic mobility shift assay

PCR polymerase chain reaction 
play a prominent role, as evidenced by mutations that are frequently related to human tooth agenesis. Nonsyndromic tooth agenesis can be either sporadic or familial in nature. To date, heterozygous mutations of 2 transcription factors, PAX9 and MSX1, have been most commonly associated with this form of tooth agenesis [Kapadia et al., 2007]. While MSX1 mutations have been reported to involve cleft lip and palate [van den Boogaard et al., 2000] and Witkop syndrome [Jumlongras et al., 2001], along with missing teeth, all known PAX9 mutations are associated with nonsyndromic oligodontia that can involve all types of permanent teeth, especially molars. Collectively, these data suggest that $P A X 9$ plays a dominant role in the development of posterior teeth [Stockton et al., 2000; Nieminen et al., 2001; Das et al., 2002; Frazier-Bowers et al., 2002; Das et al., 2003; Lammi et al., 2003; Mostowska et al., 2003; Jumlongras et al., 2004; Klein et al., 2005; Zhao et al., 2005; Kapadia et al., 2006; Mostowska et al., 2006; Tallón-Walton et al., 2007].

Studies in mice with a homozygous deletion of PAX9 demonstrate that it has a fundamental role during development [Peters et al., 1998]. These mice lack derivatives of the pharyngeal pouch, have craniofacial and limb anomalies, and fail to form teeth beyond the bud stage of development. Human PAX9 mutations afford a unique opportunity to investigate how these alterations change gene function and result in the tooth phenotype. Since the initial discovery of a tooth agenesis-causing mutation in PAX9 [Stockton et al., 2000], a spectrum of autosomal dominant mutations have been identified throughout the entire gene. The majority of mutations is located in the paired domain, the DNA-binding domain of PAX9 [Kapadia et al., 2007]. As for the functional effect of the mutations, one could predict that the mutant proteins, especially those resulting from a frameshift or nonsense mutation, may result in total loss of function [Stockton et al., 2000; Das et al., 2002, 2003; Klein et al., 2005; Mostowska 2006; Tallón-Walton 2007]. This would imply that haploinsufficiency could be the cause of tooth agenesis. Recent studies of the mutant proteins showed that the loss of DNA binding may explain changes in function [Kapadia et al., 2006; Ogawa et al., 2006]. However, the precise mechanisms for the development of tooth agenesis remain unclear.

In this study, we report the identification of 2 novel missense mutations in the paired domain of PAX9 in Chinese patients with nonsyndromic tooth agenesis. Based on our functional analysis of the mutant proteins, we propose that the severity of the tooth agenesis phenotypes correlates with the level of functional defects, spe- cifically DNA binding, observed for the respective mutant proteins. This is suggestive of distinct genotype-phenotype correlations for $P A X 9$ mutations.

\section{Materials and Methods}

\section{Subjects}

Fourteen unrelated individuals with selective tooth agenesis who showed no signs of other congenital abnormalities or systemic diseases were recruited from the Department of Prosthodontics, School of Stomatology, Peking University. The inclusion criterion was congenital agenesis of at least 1 permanent tooth, not including third molars, as verified by panoramic radiographs and dental history. The family members of all patients were clinically examined and 4 of 14 had 1 family member each who was also affected. In addition, a questionnaire was given to each individual to gather a medical and family history. Seventy individuals with normal number and shape of teeth were recruited as controls. The present study was approved by the Ethics Committee of the Peking University Health Science Center. Informed consent was obtained from all participants, including patients and normal controls.

\section{Mutational Analysis}

Peripheral blood samples were obtained for all patients and family members. Buccal swabs were taken from the 70 normal controls. Genomic DNA was isolated and all 4 exons of PAX9 were amplified by polymerase chain reaction (PCR) as previously described [Nieminen et al., 2001]. Denaturing high-performance liquid chromatography (DHPLC) was then performed using the WAVEs DNA Fragment Analysis System (Transgenomic Inc., Beijing, China). The PCR products, which showed abnormal peaks in DHPLC, were gel purified and sequenced as previously described [Wang et al., 2003].

\section{Cell Culture and Transfection}

COS7 cells were grown in DMEM (Invitrogen Corp., Carlsbad, Calif., USA) supplemented with $10 \%$ fetal bovine serum and maintained at $37^{\circ} \mathrm{C}$ in the presence of $5 \% \mathrm{CO}_{2}$. They were transfected with plasmids using FuGENE 6 (Roche Diagnostics Corp., Indianapolis, Ind., USA) according to the manufacturer's instructions.

\section{Construction of Expression Plasmids and Site-Directed}

Mutagenesis

The mammalian expression vector pCMV-Pax9 with c-Myc epitope tag was used as previously described [Kapadia et al., 2006]. To construct pCMV-G6RPax9 and pCMV-S43KPax9, in vitro site-directed mutagenesis was performed using the QuikChange mutagenesis kit (Stratagene Corp., La Jolla, Calif., USA). The mutated constructs were sequenced entirely to confirm the point mutation.

Subcellular Localization

To demonstrate in vivo expression of wild-type and mutant Pax9, COS7 cells were transfected with wild-type Pax9, G6RPax9 or S43KPax9 in the pCMV-Myc vector. Immunolocalization was performed with c-Myc antibody (Santa Cruz Biotechnology Inc., 

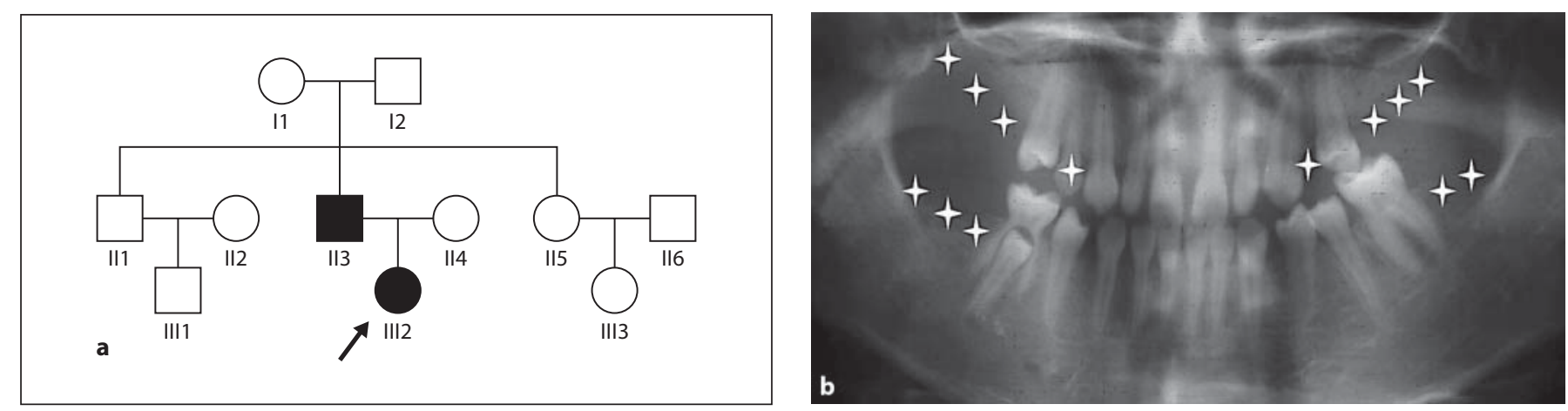

Fig. 1. a Pedigree (circles indicate females, squares indicate males) showing affectation status. The arrow indicates the proband. The pedigree displays an autosomal dominant mode of inheritance. b Panoramic radiograph of the proband (III2) at 11 years of age. Stars indicate congenitally missing teeth.

Table 1. Phenotypes of affected family members (III2, II3) and a sporadic case

\begin{tabular}{|c|c|c|c|c|c|c|c|c|c|c|c|c|c|c|c|c|c|c|c|}
\hline \multirow[t]{2}{*}{ Mutation } & \multirow[t]{2}{*}{ Case } & \multirow[t]{2}{*}{ Age } & & \multicolumn{8}{|c|}{ Right } & \multicolumn{8}{|c|}{ Left } \\
\hline & & & & 8 & 7 & 6 & 5 & 4 & 3 & 2 & 1 & 1 & 2 & 3 & 4 & 5 & 6 & 7 & 8 \\
\hline S43K & III2 & 11 & $\begin{array}{l}\text { Max } \\
\text { Man }\end{array}$ & * & $\begin{array}{l}* \\
*\end{array}$ & $\begin{array}{l}* \\
*\end{array}$ & & * & & $\mathrm{p}$ & & & $\mathrm{p}$ & & $*$ & & * & * & * \\
\hline S43K & II3 & 38 & $\begin{array}{l}\text { Max } \\
\text { Man }\end{array}$ & $\begin{array}{l}* \\
*\end{array}$ & * & & & & $*$ & $\mathrm{p}$ & & & $\mathrm{p}$ & $*$ & & & & * & $\begin{array}{l}* \\
*\end{array}$ \\
\hline G6R & sporadic & 22 & $\begin{array}{l}\text { Max } \\
\text { Man }\end{array}$ & $\begin{array}{l}* \\
*\end{array}$ & & & & & & & * & $*$ & & & & $*$ & & & $\begin{array}{l}* \\
*\end{array}$ \\
\hline
\end{tabular}

Max = Maxillary; Man = mandibular ${ }^{*}=$ congenitally missing tooth; $\mathrm{p}=$ peg-shaped tooth.

Santa Cruz, Calif., USA) as described previously [Mensah et al., 2004]. Cells were examined $24 \mathrm{~h}$ after transfection with a Leica confocal microscope. To confirm our immunocytochemistry results, nuclear and cytoplasmic fractions were obtained from cells transfected for $24 \mathrm{~h}$ using the Nuclear Extract Kit (Active Motif, Carlsbad, Calif., USA) according to the manufacturer's instructions. Western blotting was then performed using a previously established protocol [Mensah et al., 2004].

\section{Gel Shift and Super Shift Assay}

The oligonucleotide probe used for the gel shift assay was a previously established high-affinity paired domain-binding site, CD19-2(A-ins). The probe was synthesized (Sigma/Genosys, The Woodlands, Tex., USA) and gel retardation assays were performed using a LightShift Chemiluminescent EMSA Kit (Pierce Biotechnology Inc., Rockford, Ill., USA). Biotin-labeled CD19-2(A-ins) was incubated with $1 \mu \mathrm{g}$ of nuclear extracts from COS7 cells transfected with the appropriate expression plasmid (wild-type Pax9, G6RPax9 or S43KPax9 in pCMV-Myc). After incubation at room temperature for $30 \mathrm{~min}, 0.2 \mu \mathrm{g}$ of anti-c-Myc antibody (Santa Cruz Biotechnology Inc.) was added to the reaction mixture and incubated for another $5 \mathrm{~min}$. The entire reaction was loaded onto a $6 \%$ nondenaturing polyacrylamide gel. Electrophoretic mobility shift assay (EMSA) was performed in triplicate according to the manufacturer's instructions.

\section{Reporter Assay}

PAX9 expression vectors were cotransfected with a Bmp4 promoter-reporter construct (p2.4Bmp4-Luc), described previously [Ogawa et al., 2006]. pCMV-SPORT plasmid (Invitrogen Corp.) was used as the internal control. Cell extracts were prepared with Cell Culture Lysis Reagent (Promega Corp., Madison, Wisc., USA) $24 \mathrm{~h}$ after transfection and assayed by luciferase assay system (Promega Corp.) and $\beta$-gal assay kit (Invitrogen Corp.).

\section{Results}

\section{Identification of Two Novel Missense Mutations in}

Patients with Varying Degrees of Hypodontia

Two novel missense mutations in the paired domain of $P A X 9$ were identified in this group of Chinese patients 


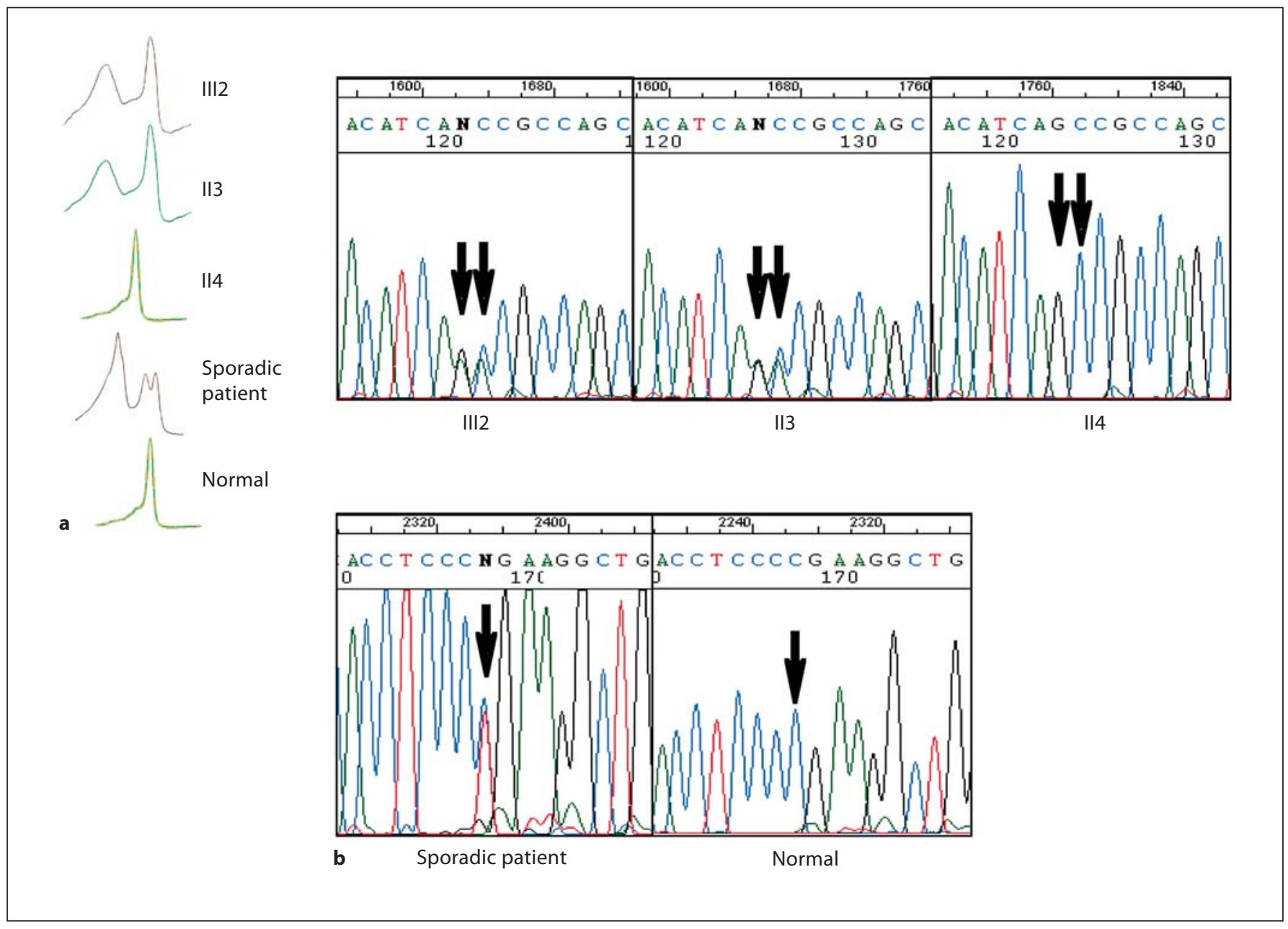

Fig. 2. DHPLC analysis (a) and sequence analysis (b) of PCR products of $P A X 9$ exon 2. DHPLC analysis showed abnormal results in the 2 patients of one family and 1 sporadic patient. Direct sequencing of the PCR products accordingly showed the point mutations in exon 2 of the PAX9 gene (indicated by arrows).

with different levels of hypodontia. The primary dentition was unaffected in all cases. Figure 1 and table 1 show the phenotypes of 3 affected individuals, 2 of whom are related. DHPLC analysis showed abnormal results in the 2 patients of one family and in 1 sporadic patient (fig. 2a). Sequencing analysis revealed 2 different mutations in exon 2 of PAX9 (fig. 2b). The 2 related individuals carried a double nucleotide mutation, G128A and C129A, which results in the substitution of serine by lysine (S43K). In the sporadic case, a novel heterozygous missense mutation, G16A, would cause a change from glycine to arginine at amino acid 6 (G6R). The pattern of tooth agenesis was significantly different between the 2 cases (table 1 ). While the individuals in the familial case (S43K) were missing most molars, the sporadic case (G6R) presented with missing mandibular central incisors and a maxillary second premolar. With the exception of the third molars, the molars were not affected. No mutations in $P A X 9$ were detected in the remainder of the patients and the 26 unaffected relatives from the families. In addition, all 70 control individuals tested lacked these 2 mutations.

\section{Affected Residues Are Evolutionarily Conserved across} PAX9 Orthologs and Related Paralogs

Sequence alignment with other members of the $P A X$ gene family, as well as the Pax9 gene in other organisms revealed $100 \%$ conservation of the 2 affected residues in the paired domain (fig. 3). 
Fig. 3. The mutations cause changes in amino acids, one from glycine to arginine (G6R) and the other from serine to lysine (S43K). Compared with the paired-domain sequence of PAX family genes and between different species, both are evolutionarily conserved.
PAX1_HUMAN PAX2 HUMAN

PAX3 HUMAN

PAX 4 HUMAN

PAX5 HUMAN

PAX 6 HUMAN

PAX7_HUMAN

PAX8 HUMAN

PAX9_HUMAN

PAX1_HUMAN

PAX2 HUMAN

PAX3_HUMAN

PAX 4_HUMAN

PAX5 HUMAN

PAX6 6 HUMAN

PAX7 7 HUMAN

PAX8 HUMAN

PAX9_HUMAN

PAX1 MOUSE

PAX2 MOUSE

PAX3 MOUSE

PAX4 MOUSE

PAX5 MOUSE

PAX 6 MOUSE

PAX7 MOUSE

PAX8 MOUSE

PAX9 $9^{-}$MOUSE

PAX9_HUMAN

PAX1 MOUSE

PAX2 MOUSE

PAX3 MOUSE

PAX 4 MOUSE

PAX5 MOUSE

PAX6 MOUSE

PAX7_MOUSE

PAX8 MOUSE

PAX9 MOUSE

PAX9_HUMAN

PAX9_CHICK

PAX9 MOUSE

PRD DROME

PAX $\overline{9}$ _HUMAN

PAX9 CHICK

PAX9 MOUSE

PRD DROME

PAX9_HUMAN $\ldots \ldots \ldots \ldots \ldots \ldots \ldots \ldots \ldots$ MEQTYGEVNQ LGGVFVNGRP $\ldots \ldots \ldots \ldots$ MD MHCKADPFSA MHPGHGGVNQ LGGVEVNGRP MTTLAGAVPR MMRPGPGQNY PRSGFPLEVS TPLGOGRVNQ LGGVFINGRP $\ldots \ldots \ldots \ldots \ldots \ldots \ldots \ldots \ldots \ldots \ldots \ldots$ HQDGIS $\$ \ldots M N Q$ LGGLFVNGRP $\ldots \ldots \ldots \ldots$ MD LEKNYPTPRT SRTGHGGVNQ LGGVFVNGRP $\ldots \ldots \ldots \ldots \ldots \ldots \ldots \ldots \ldots \ldots$ MQNSHSGVNQ LGGVEVNGRP MAALPGTVPR MMRPAPGQNY PRTGFPLEVS TPLGOGRVNQ LGGVEINGRP $\ldots \ldots \ldots \ldots \ldots \ldots \ldots \ldots \ldots \ldots$ MPHS IRSGHGGLNQ LGGAFVNGRP $\ldots \ldots \ldots \ldots \ldots \ldots$ MEPAFGEVNQ LGGVFVNGRP

LPNAIRLRIV ELAQLGIRPC DISRQLRVSH GCVSKILARY NETGSILPGA LPDVVRORIV ELAHOGVRPC DISROLRVSH GCVSKILGRY YETGSIKPGV LPNHIRHKIV EMAHHGIRPC VISRQLRVSH GCVSKILCRY QETGSIRPGA LPLDTRQQIV RLAVSGMRPC DISRILKVSN GCVSKILGRY YRTGVLEPKG LPDVVRORIV ELAHOGVRPC DISROLRVSH GCVSKILGRY YETGSIKPGV LPDSTRQKIV ELAHSGARPC DISRILQVSN GCVSKILGRY YETGSIRPRA LPNHIRHKIV EMAHHGIRPC VISRQLRVSH GCVSKILCRY QETGSIRPGA LPEVVRORIV DLAHOGVRPC DISROLRVSH GCVSKILGRY YETGSIRPGV LPNAIRLRIV ELAQLGIRPC DISRQLRVSH GCVSKILARY NETGSILPGA

$\ldots \ldots \ldots \ldots \ldots$ MEQTYGEVNo LGGVFVNGRP $\ldots \ldots \ldots \ldots$.....MDMHCK ......ADPFS AMHRHGGVNQ LGGVFVNGRP MTTLAGAVPR MMRPGPGQNY PRSGFPLEVS TPLGQGRVNQ LGGVEINGRP

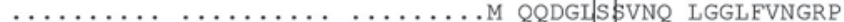
$\ldots \ldots \ldots \ldots$.... $\ldots$ MDLEKNY ....PTPRT IRTGHGGVNQ LGGVFVNGRP $\ldots \ldots \ldots \ldots \ldots \ldots \ldots$ MQNSHS GVNQ LGGVFVNGRP MAALPGAVPR MMRPGPGQNY PRTGFPLEVS TPLGOGRVNQ LGGVFINGRP $\ldots \ldots \ldots \ldots \ldots \ldots \ldots \ldots \ldots$ MPHN IRSGHGGLNQ LGGAFVNGRP $\ldots \ldots \ldots \ldots \ldots \ldots$ MEPAFGEVNQ LGGVFVNGRP $\ldots \ldots \ldots \ldots \ldots \ldots \ldots \ldots$ MEPAFGEVNQ LGGVFVNGRP

LPNAIRLRIV ELAQLGIRPC DISRQLRVSH GCVSKILARY NETGSILPGA LPDVVRORIV ELAHOGVRPC DISROLRVSH GCVSKILGRY YETGSIKPGV LPNHIRHKIV EMAHHGIRPC VISRQLRVSH GCVSKILCRY QETGSIRPGA LPLDTRQQIV QLAIRGMRPC DISRSLKVSN GCVSKILGRY YRTGVLEPKC LPDVVRQRIV ELAHQGVRPC DISRQLRVSH GCVSKILGRY YETGSIKPGV LPDSTRQKIV ELAHSGARPC DISRILQVSN GCVSKILGRY YETGSIRPRA LPNHIRHKIV EMAHHGIRPC VISRQLRVSH GCVSKILCRY QETGSIRPGA LPEVVRORIV DLAHOGVRPC DISROLRVSH GCVSKILGRY YETGSIRPGV LPNAIRLRIV ELAQLGIRPC DISRQLRVSH GCVSKILARY NETGSILPGA LPNAIRLRIV ELAQLGIRPC DISRQLRVSH GCVSKILARY NETGSILPGA

$\ldots \ldots \ldots \ldots \ldots \ldots \ldots \ldots$ PAFGE VNQI GFVEVN GRPLPNAIRL $\ldots \ldots \ldots \ldots \ldots \ldots$ MEPAFGE VNQI GEVEVN GRPLPNAIRL MTVTAFAAAM HRPFFNGYST MQDMNSGQGR VNQI GGVEIN GRPLPNNIRL $\ldots \ldots \ldots \ldots \ldots \ldots \ldots \ldots$ MEPAFGE VNQIGGVFVN GRPLPNAIRL

RIVELAOLGI RPCDISRQLR VSHGCVSKIL ARYNETGSIL PGAIGGSKPR RIVELAQLGI RPCDISRQLR VSHGCVSKIL ARYNETGSIL PGAIGGSKPR KIVEMAADGI RPCVISRQLR VSHGCVSKIL NRYQETGSIR PGVIGGSKPR RIVELAQLGI RPCDISRQLR VSHGCVSKIL ARYNETGSIL PGAIGGSKPR

\section{G6R and S43K Do Not Change Nuclear Localization of PAX9}

COS7 cells transfected with an expression vector encoding either wild-type or mutant Myc-tagged PAX9 showed predominantly nuclear expression by immunofluorescence $24 \mathrm{~h}$ after transfection (fig. $4 \mathrm{a}$ ). Western blot analysis of nuclear and cytoplasmic fractions of COS7 cells $24 \mathrm{~h}$ following transfection showed similar results (fig. 4a), confirming that these 2 mutations did not affect nuclear localization of $P A X 9$.

\section{G6R and S43K Mutations Cause Decrease in Affinity for DNA}

As a transcription factor, PAX9 is likely able to regulate its effector genes by binding to promoter sequences via the paired domain. CD19-2(A-ins), an established paired domain-binding sequence, was chosen to test if the 2 novel mutations affect the DNA-binding ability of PAX9. First, Western blots were performed from nuclear extracts of COS7 transfected with wild-type or mutant $P A X 9$ expression vector to verify equal expression levels of the proteins. Our EMSA results revealed that both 


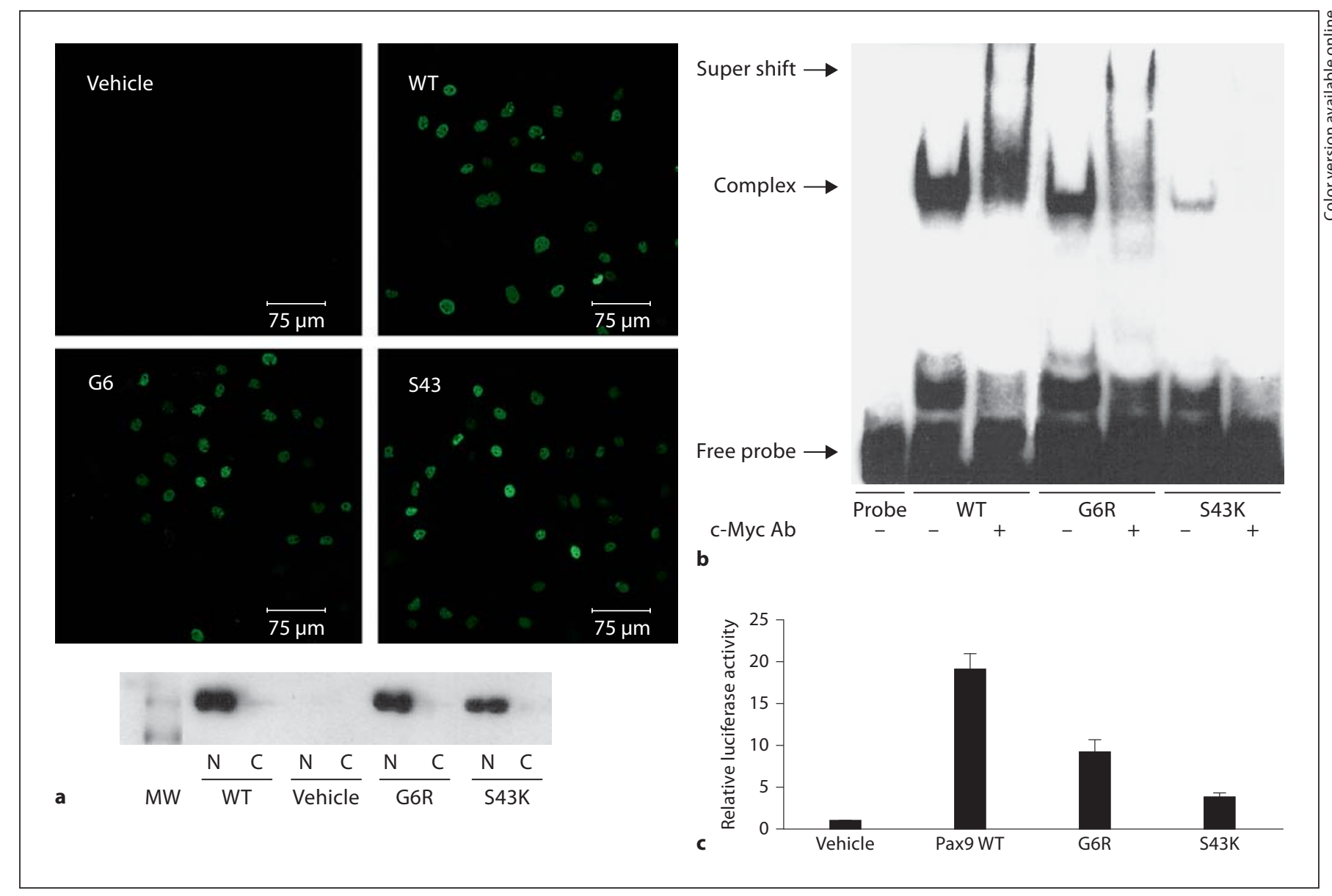

Fig. 4. a Subcellular localization of G6R and S43K mutant protein does not show any differences when compared to normal protein by immunofluorescence and immunoblotting. $\mathbf{b}$ Gel shift and super shift assay of nuclear extracts from $P A X 9$ overexpression COS7 cells shows that like wild-type PAX9, both G6R and S43K mutant proteins could form DNA-protein complexes. However, G6R has a higher affinity for DNA than S43K. c Luciferase re- porter assay using the Bmp4 promoter shows that both G6R and S43K mutant proteins have diminished transcriptional activity. The G6R mutant, however, is able to transcriptionally activate the Bmp4 promoter at a higher level than $\mathrm{S} 43 \mathrm{~K}$. The figure represents the results in triplicate. $\mathrm{N}=$ Nucleus; $\mathrm{C}=$ cytoplasm; $\mathrm{MW}=$ molecular weight marker; $\mathrm{WT}=$ wild type; $\mathrm{Ab}=$ antibody. mutant proteins have a reduced ability to bind DNA when compared to the wild-type protein. However, the G6R mutant protein had higher affinity for DNA than S43K (fig. 4b).

\section{G6R and S43K Affect Reporter Gene Expression}

To further study the in vivo function of the mutant proteins, a luciferase reporter assay was used to test the ability of the proteins to transcriptionally regulate a downstream effector gene, Bmp4. Using a Bmp4 promoter reporter construct, the luciferase reporter assay showed a significant reduction in transcriptional activation for both mutants when compared to the wild-type protein.
While there was a 2-fold reduction in transcription activity by the G6R protein, the S43K mutant displayed a nearly 5 -fold reduction in activity (fig. 4c).

\section{Discussion}

In this report, we describe the identification of 2 novel missense mutations in the $P A X 9$ gene in Chinese patients with nonsyndromic hypodontia. Both mutations (G6R and S43K) localize to the paired domain of PAX9 and are predicted to affect highly conserved amino acid residues. The clinical phenotypes of the 2 cases are dif- 
ferent in terms of severity: excluding the third molar, the patient carrying the G6R mutation is missing only 2 mandibular incisors and 1 maxillary premolar, while patients from the family with the S43K mutation may be missing a number of teeth, including molars, maxillary premolars and mandibular canines. Our functional analysis showed that, although neither mutation altered nuclear localization, the ability to bind DNA and transcriptionally activate a target gene was dramatically reduced. Interestingly, both EMSA and reporter assays showed that G6R protein retained more DNA-binding and transcriptional activation capability, corresponding with the clinical observation of tooth phenotypes. We propose that this loss of function correlates well with the observed phenotypes.

$P A X 9$ as a candidate gene for nonsyndromic tooth agenesis was first reported nearly 7 years ago [Stockton et al., 2000]. Since this initial discovery, other mutations have been identified which present with different phenotypes. Most involved molars, especially the second molars. In this study, the G16A (G6R) mutation shows a surprisingly mild and atypical phenotype where first and second molars were unaffected. While studies in mice have clearly shown that $P A X 9$ dosage is critical for tooth morphogenesis and differentiation [Kist et al., 2005], the study of naturally occurring mutations in humans affords a unique opportunity to relate different tooth agenesis phenotypes to gene function.
It should be noted that in 15 of the 18 unrelated patients investigated with typical symptoms of nonsyndromic hypodontia, no mutations were found in the coding regions of $P A X 9$. This suggests other genes such as MSX1, AXIN2 or some critical noncoding regions of these genes may have variations responsible for the tooth agenesis. Other than syndromic hypodontia, which usually has a clear genetic basis, nonsyndromic hypodontia has an evident difference between the high incidence rate and the relatively small number of reported causative mutations in PAX9, MSX1 or other genes [Gerits et al., 2006]. Thus, it seems that the effect of genetics on tooth agenesis probably is much more heterogeneous than we had expected.

\section{Acknowledgements}

We thank the patients and control subjects for their willing cooperation and participation, Dr. Dalong Ma for his critical discussion and review of the manuscript, Adriana Cavender for assistance in preparation of the manuscript, and members of the Peking University Human Disease Genomics Center for their excellent technical assistance. This work was supported by NIH U24 DE16472 to R.N.D., TAMHSC-VPR grant to H.K., NIH K08 DE16346 to H.K. and the Beijing Natural Science Foundation (7063099).

\section{References}

Das, P., D.W. Stockton, C. Bauer, L.G. Shaffer, R.N. D'Souza, T. Wright, P.I. Patel (2002) Haploinsufficiency of PAX9 is associated with autosomal dominant hypodontia. Hum Genet 110: 371-376.

Das, P., M. Hai, C. Elcock, S.M. Leal, D.T. Brown, A.H. Brook, P.I. Patel (2003) Novel missense mutations and a 288-bp exonic insertion in PAX9 in families with autosomal dominant hypodontia. Am J Med Genet 118: 35-42.

Frazier-Bowers, S.A., D.C. Guo, A. Cavender, L. Xue, B. Evans, T. King, D. Milewicz, R.N. D'Souza (2002) A novel mutation in human PAX9 causes molar oligodontia. J Dent Res 81: $129-133$.

Gerits, A., P. Nieminen, S. De Muynck, C. Carels (2006) Exclusion of coding region mutations in MSX1, PAX9 and AXIN2 in eight patients with severe oligodontia phenotype. Orthod Craniofac Res 9: 129-136.
Jumlongras, D., M. Bei, J.M. Stimson, W.F. Wang, S.R. DePalma, C.E. Seidman, U. Felbor, R. Maas, J.G. Seidman, B.R. Olsen (2001) A nonsense mutation in MSX1 causes Witkop syndrome. Am J Hum Genet 69: 67-74.

-Jumlongras, D., J.Y. Lin, A. Chapra, C.E. Seidman, J.G. Seidman, R.L. Maas, B.R. Olsen (2004) A novel missense mutation in the paired domain causes nonsyndromic oligodontia. Hum Genet 114: 242-249.

Kapadia, H., S.A. Frazier-Bowers, T. Ogawa, R.N. D'Souza (2006) Molecular characterization of a novel PAX9 missense mutation causing posterior tooth agenesis. Eur J Hum Genet 14: 403-409.

Kapadia, H., G. Mues, R. N. D’Souza (2007) Genes affecting tooth morphogenesis. Orthod Craniofac Res 10: 237-244.

Kist, R., M. Watson, X. Wang, P. Cairns, C. Miles, D.J. Reid, H. Peters (2005) Reduction of Pax9 gene dosage in an allelic series of mouse mutants causes hypodontia and oligodontia. Hum Mol Genet 14: 3605-3617.
Klein, M.L., P. Nieminen, L. Lammi (2005) Novel mutation of the initiation codon of PAX9 causes oligodontia. J Dent Res 84: 43-47.

Lammi, L., K. Halonen, S. Pirinen, I. Thesleff, S. Arte, P. Nieminen (2003) A missense mutation in PAX9 in a family with distinct phenotype of oligodontia. Eur J Hum Genet 11: 866-871.

Mensah, J.K., T. Ogawa, H. Kapadia, A.C. Cavender, R.N. D’Souza (2004) Functional analysis of a mutation in PAX9 associated with familial tooth agenesis in humans. J Biol Chem 279: 5924- 5933.

Mostowska, A., A. Kobielak, B. Biedziak, W.H. Trzeciak (2003) Novel mutation in the paired box sequence of PAX9 gene in a sporadic form of oligodontia. Eur J Oral Sci 111: 272276.

Mostowska, A., B. Biedziak, W.H. Trzeciak (2006) A novel mutation in PAX9 causes familial form of molar oligodontia. Eur J Hum Genet 14: 173-179. 
-Nieminen, P., S. Arte, D. Tanner, L. Paulin, S. Alaluusua, I. Thesleff, S. Pirinen (2001) Identification of a nonsense mutation in the PAX9 gene in molar oligodontia. Eur J Hum Genet 9: 743-746.

Ogawa, T., H. Kapadia, J.Q. Feng, R. Raghow, H. Peters, R.N. D'Souza (2006) Functional consequences of interactions between $\operatorname{Pax} 9$ and Msx1 genes in normal and abnormal tooth development. J Biol Chem 281: 1836318369.

- Peters, H., A. Neubüser, K. Kratochwil, R. Balling (1998) Pax9-deficient mice lack pharyngeal pouch derivatives and teeth and exhibit craniofacial and limb abnormalities. Genes Dev 12: 2735-2747.
Stockton, D.W., P. Das, M. Goldenberg, R.N. D'Souza, P.I. Patel (2000) Mutation of PAX9 is associated with oligodontia. Nat Genet 24: 18-19.

-Tallón-Walton, V., M.C. Manzanares-Céspedes, S. Arte, P. Carvalho-Lobato, I. ValdiviaGandur, A. Garcia-Susperregui, F. Ventura, P. Nieminen (2007) Identification of a nove mutation in the PAX9 gene in a family affected by oligodontia and other dental anomalies. Eur J Oral Sci 115: 427-432.

Thesleff, I. (2003) Epithelial-mesenchymal signalling regulating tooth morphogenesis. J Cell Sci 116: 1647-1648.
Thesleff, I. (2006) The genetic basis of tooth development and dental defects. Am J Med Genet A 140: 2530-2535.

van den Boogaard, M.J., M. Dorland, F.A. Beemer, H.K. van Amstel (2000) MSX1 mutation is associated with orofacial clefting and tooth agenesis in humans. Nat Genet 24: 342-343.

Wang, Y., H. Zhao, X. Zhang, H. Feng (2003) Novel identification of a four-base-pair deletion mutation in PITX2 in a Rieger syndrome family. J Dent Res 82: 1008-1012.

Zhao, J.L., Y.X. Chen, L. Bao, Q.J. Xia, T.J. Wu, L. Zhou (2005) Novel mutations of PAX9 gene in Chinese patients with oligodontia. Chin J Stomatol 40: 266-269. 